\title{
Tokyo HIV-contaminated blood product hearing
}

After more than five years of testimony and debate, a case brought by haemophiliacs infected with the human immunodeficiency virus (HIV) drew to a close at the Tokyo District Court on 27 March. The plaintiffs are suing the Japanese government, a government-related foundation and four pharmaceutical companies. They claim that their infection by contaminated blood products imported from the United States could have been avoided if the defendants had acted more quickly to approve and supply products that had been heat-treated to destroy HIV and other viruses.

The case, which began in October 1989, was originally brought by 14 HIV-infected haemophiliacs. Five more suits involving another 77 haemophiliacs followed. It is the hearing of the first four suits, involving 47 plaintiffs, that has ended. They are seeking $¥ 5.3$ billion (US\$60 million) in damages. Already 33 of the 91 affected individuals have died of AIDS and are now represented by their families. The plaintiffs' lawyers, stressing that their clients have short life expectancies, have asked for a quick decision but a judgement is not expected until this autumn at the earliest.

The defendants are the Japanese government, the Chemo-Sero-Therapeutic Research Institute (Kaketsuken), a Tokyobased non-profit organization, and four drug companies, Midori Juji (Green Cross Corporation), Baxter Travenol, Bayer Yakuin and Nippon Zoki Pharmaceutical Company. Lawyers for the prosecution argue that misconduct by government officials and pursuit of profits by drug companies led to an unnecessary delay in the importation of heat-treated blood products. These were approved by the US Food and Drug Administration in March 1983, and the US began to withdraw untreated products in 1984. Progress in Japan, however, was much slower.

In June 1983, the Japanese Ministry of Health and Welfare set up an AIDS study group headed by Takeshi Abe of Teikyo University in Tokyo. Two months later the National Association of Haemophiliacs petitioned the ministry to find substitutes for untreated blood products after safety fears grew. In November 1983, however, the ministry decided to continue with nonheat-treated products while the heattreated ones underwent clinical trials in Japan, a move in which Abe was a key proponent. The plaintiffs say that the dangers were clear by 1983 and that numerous signs were either ignored or covered up by ministry officials.

Between 1983 and 1985, the importation of untreated blood concentrates actually increased by about 40 per cent as the ministry and doctors encouraged the use of products from the US, which haemophiliacs could administer at home. High retail prices in Japan and a rapidly disappearing home market for untreated products provided a strong incentive to American exporters. Heat-treated products were finally given Japanese government approval in July 1985. However, manufacturers continued to advertise the availability of untreated products without warning until late 1985, and they were in use by Japanese haemophiliacs until 1986. As a result, almost 1,800 haemophiliacs were infected with HIV. This represents about 40 per cent of Japan's haemophiliac population and almost 50 per cent of all known HIV cases in this country. AIDS has already claimed the lives of more than 300 Japanese haemophiliacs.

In their defence, the Ministry and drug companies say that at the time informa-

tion about the risks of HIV infection and AIDS was scant. For example, some experts did not accept HIV as the primary cause of AIDS until a paper published in Science in May 1984. So, while the defendants have offered compensation to the individuals concerned, they deny any legal responsibility. Abe has countered personal accusations by pointing out that if his committee had agreed to the importation of heat-treated products without first carrying out clinical trials in Japan, they would have been blamed if any sideeffects had later become apparent.

A similar case brought against the same organizations by another 97 plaintiffs is underway in Osaka. This began in May 1989, just before the Tokyo case, but the hearing is not expected to conclude until this July.

Discrimination against HIV and AIDS sufferers is still widespread in Japan. In another landmark judgement announced at the end of March, a 35-year-old man who lost his job at a software company in 1992 after a medical checkup revealed that he was HIV-positive, was awarded $¥ 6$ million (US\$68,000) by the Tokyo District Court. This decision is seen as an important victory for the rights of HIV carriers in Japan and has been widely praised.

No one is publicly predicting the outcome of the haemophiliacs' case. The haemophiliacs had no choice but to use the untreated blood products, and public sympathy for them is running high.

TIMO HANNAY

Tokyo

\section{Tobacco company withdraws claim}

The Brown \& Williamson Tobacco Co. has withdrawn its claim to about onethird of a disputed cache of 4,000 pages of internal documents held at the library of the University of California at San Francisco (UCSF). A law suit to determine who owns the rest is still pending.

The documents purport to show that tobacco company executives have known for more than 30 years that nicotine is harmful but have attempted to suppress the information. The tobacco company has maintained that the documents were stolen and has demanded not only their return, but the names of individuals who had access to them and details on their research. UCSF maintains the documents are in the public domain and has refused to return them or to divulge the names of those who have seen them. The university also has alleged that Brown \& Williamson tried to intimidate certain individuals wishing to study the papers, even to the point of stationing private investigators in the school's library to see who asks for access.

The disputed portion of the file will remain closed to the public until a court hearing is held later this month.

Lawyers for the Louisville-based firm 